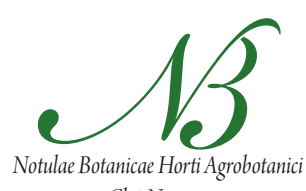

Cluj-Napoca

\title{
Evaluation of Betulin and Betulinic Acid Content in Birch Bark from Different Forestry Areas of Western Carpathians
}

\author{
Liviu HOLONEC, Floricuța RANGA, Diana CRAINIC, Alina TRUȚA, Carmen SOCACIU* \\ University of Agricultural Sciences and Veterinary Medicine, 3-5 Manastur Street, 400372 Cluj \\ Napoca, Romania; carmen.socaciu@usamvcluj.ro (*corresponding author)
}

\begin{abstract}
In order to evaluate the content of betulin and betulinic acids in Birch barks originating from Western Carpathians, Transylvania (Romania) forests, in relation with the location of birch trees, it was recorded the geographic and vegetation conditions at the specific locations of each type of sample. Two groups of birch tree bark (totally 10 samples) were collected, from two regions, pasture surfaces where birch trees appeared spontaneously (samples 1 to 5) and another group from forests of combined trees, including mainly pine trees (samples 6 to 10). The identification and quantitation of betulin and betulinic acid were made by High Performance Liquid Chromatography with UV detection. In the first region it has been found mean concentrations of $126.85 \pm 12.56 \mathrm{mg} / \mathrm{g}$ betulin bark while acid betulinic had average values of $12.78 \pm 1.26 \mathrm{mg} / \mathrm{g}$ bark. In the second region we found mean concentrations of $89.84 \pm 8.43$ $\mathrm{mg} / \mathrm{g}$ betulin of bark while acid betulinic had average values of $10.60 \pm 0.97 \mathrm{mg} / \mathrm{g}$ bark. Statistically, significant differences were noticed between the two regions, the first region being richer in these molecules. Generally, the percentage of betulinic acid was around $11.23 \%$ against betulin, higher in the second region, even the absolute concentrations were lower for both molecules. These data are useful indicators of the potential offered by birch bark sources found in Transylvania region, to obtain extracts enriched in betulin and betulinic acid.
\end{abstract}

Keywords: Betula pendula, betulin, betulinic acid, HPLC, Western Carpathian forest

\section{Introduction}

Romania is a rich country considering the variety of birch forests. It can be found four main species (Betula pendula Roth., Betula pubescens Ehrh., Betula humilis Schrank. and Betula nana L.) out of them, the „common birch” (Betula pendula Roth.) being the most known, mainly present in Western Carpathians, inside forests or spread in the pasture areas (Dehelean et al., 2007; KovacBesovic et al., 2009 a; Stănescu, 1979). Having a pronounced "pioneer" character, due to its "rusticity", the common birch appears spontaneously, filling the empty surfaces after cuttings of other trees or after calamities (Şofletea and Curtu, 2000). It is characterized by high ecologic amplitude, developing without any special conditions. By its unique shape and white appearance of the bark, by its peculiar foliage, it is also a very decorative tree (Conway, 2002; Haralamb, 1956). The birch wood has hard proprieties, generally used for carpentry or even in aquatic industry. It is a good source of methanol, vinegar, coal and the bark, rich in tannins was mainly used to obtain heavy hydrocarbons and lubricant oils (Zhao et al., 2007). The concentration of tannins (around 1.6\%) especially located in the suberosis part recommend it for tanning industry. By dry distillation, the oil extracted is used as skins moisture or to be used as lighting fuel (especially in the North of Europe) (Wan et al., 2012).
The birch bark is formed of a white suberos epidermal with multiple layers which exfoliates in narrow foils. Almost half of it contains a sort of resin which contains betulins, which confer a high capacity of preservation for longtime, demonstrated by its occurrence in the turba and coal (lignite) deposits. The foliage is useful for other significant substances, including flavonoids (Lahtinen et al., 2006; Tamas et al., 1978), which can be valorized for different products (EMA, 2007; Hoppe, 1975, Ladynina and Morozova, 1987; Vermeulen, 1999). The borch sap is also a useful product containing carbohydrates $(8.7 \%)$, a mature tree producing in 24 hours, around 170-240 liters of sap (Fulda, 2008). The birch bark is also known as an antipyretic agent (Hoppe, 1975), containing 4-5\% tannins and essential oils. Betulin, a resinous triterpene similar to lupeol, and the glycoside betuloside with the aglycone betuligenol are found in bark (Gessner, 1974; Kovac-Besovic et al., 2009 b).

Betulinic acid is a minor bio-compound but with a high efficacy in treating different diseases. Interest in betulin has increased recently as certain derivatives from this composition are considered to be a potential agent against tumor cancer (Alakurtti et al., 2006; Oh et al., 2006; Sami et al., 2006) tested on brain, skin or other tumor cells (Fulda et al., 1999; Pezzuto et al., 1999; Rajendran et al., 2008), as well in the chronic hepatitis therapy (Shikov et al., 2011). 
100

Betulinic acid has anti-malarial, anti-inflammatory antiviral, anti-HIV activities and cytotoxicity against a variety of tumor cell lines comparable to some clinically used drugs (Cichewicz and Kouzi, 2004; Fulda, 2008; Kvasnica et al., 2005). Betulinic acid has also been found that it can retard the progression of HIV-1 infection, which eventually leads to AIDS, by preventing the formation of syncytium (cellular aggregates) (Crevelin et al., 2006; Zuco et al., 2002).

The identification was made by spectrometry (O'Connell et al., 1998), by HPLC (Ossipov et al., 1996; Zhao et al., 2007) or by vibrational spectroscopy (Cântă Pânzaru et al., 2002; Falamas et al., 2011).

Outer bark of birch (Betula alba cortex) contains pentacyclic triterpenes, mainly betulin (BE, up to $34 \%$ ), but also betulinic acid (BA), oleanolic acid (OA), lupeol (LU) and erythrodiol (ER). They can be extracted as a triterpene rich dry extract (TE) which is able to form a topically applicable oleogel (Ekman, 1983; Laszczyk et al., 2006; Lavrjonov and Lavrjonova, 2003).

Betula alba is used also in homeopathy, basically as a natural diuretic as well as against gastric aches (Mihailov, 2002). The buds contain 4-6\% of essential oil (Gessner, 1974), and is used as a diuretic drug (Turova, 1974) (Gemmae Betulae). Oleum Betulae empyreumaticum rectificatum is the oil obtained by the dry distillation of the bark and wood of Betula alba and rectified by steam distillation. The external application of betulin is recommended in parasitic infestation of the skin with subsequent hair loss, rheumatism and gout, dry eczema and dermatoses, psoriasis and other chronic skin diseases (Ladynina and Morozova, 1987; Muravjova et al., 2002; Turova, 1974). The dry distillation of birch wood yields about $6 \%$ phenols (cresole, quajacole, xylenole, coesole). In veterinary medicine the oleum, Betulae empyreumaticum rectificatum, in known as vermifuge (Gessner, 1974).

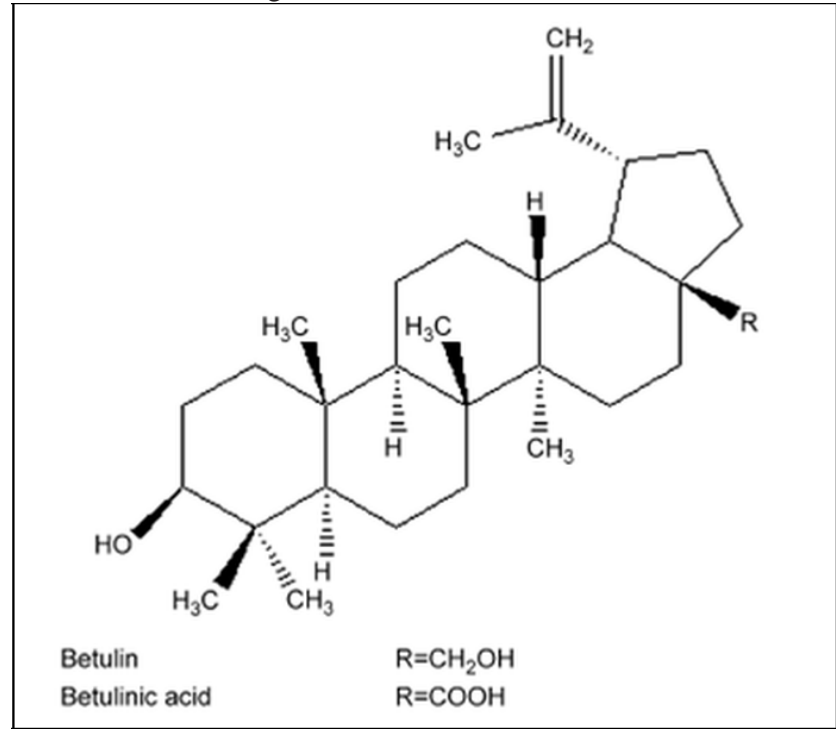

Fig. 1. Chemical structures of betulin and betulinic acid found, main triterpenoids with diverse bioactivities from the birch bark
Betulin and betulinic acid are pentacyclic triterpenes present in the bark of the birch tree and other vegetal sources. Quantitatively, in birch bark betulin is more significant than betulinic acid; therefore, birch can be a large and feasible source of raw material for betulin extraction (Soica et al., 2012; Yin et al., 2008).

The common birch found in Western Carpathians (Transylvania region of Romania) is a middle size tree (rarely taller than $25 \mathrm{~m}$ ) with a thin trunk, larger at bottom, sometimes with irregularities in growth. The young trees have white bark which exfoliates easily, while in the old trees bark have harder dark black "ritidom", especially at the bottom. The branches crown is not well developed, irregular, with oval-pyramid shape and thin branches inserted obliquely in the trunk.

Betulin (3-lup-20(29)-en-3,28-diol) and betulinic acid (3-hydroxy-lup-20(29)-en-28-oic acid) are pentacyclic lupane type triterpenoids (Fig. 1) which can be easily isolated and purified. The birch tree (Betula spp., Betulaceae) is one of the substantial sources for both the molecules (Hayek et al., 1989).

In the present study it was investigate the composition in betuline and betulinic acid of different birch tree barks found in forestry areas of Western Carpathians, bioactive molecules which can be valorized by biorefinery techniques.

\section{Materials and methods}

\section{Specific areas for harvesting the birch bark samples}

In order to correlate the content of betulin and betulinic acids found in samples, with the location of birch trees, it has been recorded the geographic and vegetation conditions at the specific locations of each type of sample. There were collected bark samples of similar ages, from different areas and trunk diameters, from different mountain areas of Western Carpathians.

Two groups of birch tree bark samples were collected: one group (samples 1 to 5) from pasture surfaces where birch trees appeared spontaneously and another group (samples 6 to 10) from forests of combined trees, including mainly pine trees. The average age of trees was 20 years in all cases and the trunk diameter of $10-12 \mathrm{~cm}$ at $1.3 \mathrm{~m}$ height from the soil level. The samples were transversal cuttings of $10 \mathrm{~cm}$ length and $10-12 \mathrm{~cm}$ diameter. All the collected barks were immediately dried at $60^{\circ} \mathrm{C}$ and stored in a dry and dark place.

The first lot of samples (1 to 5) was harvested from birch tree found in pasture areas, in the villages Beliş, Râş̧ca, Dângău, Mărişel and Paraul Porcului. The trees were situated in the high hilly and pre-mountain areas, is situated at $46^{\circ} 65^{\prime}$ latitude North, $23^{\circ} 03^{\prime}$ longitude East and a altitude between $900 \mathrm{~m}$ and $1050 \mathrm{~m}$ a.s.l., with sunny exhibition and different slopes (Fig. 2). The environmental and vegetation conditions were similar. According to classification Koppen, the general climate is „D.f.c.k.” meaning "humid, 
rainy with cold winters", and with annual average temperatures in the warmest season, above $10^{\circ} \mathrm{C}$. The dryness index ranged between 57 and 63 (mean value $=60$ ).

The second lot of samples (6 to 10) (Tab. 1) were collected from birch trees found in the basin „Valea Ierii”, is situated at $46^{\circ} 65^{\prime}$ latitude North, $23^{\circ} 35^{\prime}$ longitude East and a medium altitude of $1000 \mathrm{~m}$ a.s.l. with similar conditions, but with different slopes from the area (nr. 7, 8 and 9) or outside the forests (nr. 6 and 10) (Fig. 3). According to Koppen climate classification, the tress are situated in boreal, D.f.k., characterized by cold and humid winters, with average temperatures, in warm seasons, above $10^{\circ} \mathrm{C}$, and $-4^{\circ} \mathrm{C}$ in the cold season. It is a specific pre-mountain and mountain vegetation with pines, larch, spruce fir etc., as detailed in Tab. 1 .

\section{Chemical analysis}

The betulin and betulinic acid were extracted from dried birch barks and analyzed at the Department of Chemistry and Biochemistry at the University of Agricultural Sciences and Veterinary Medicine Cluj-Napoca, using High Performance Liquid Chromatography with ultraviolet detection (HPLC-UV). Pure standards of betulin and betulinic acid (provided from Roth, $\mathrm{GmbH}$ Germany) were used to build a calibration curve, in order to make quantitative evaluations. From each white bark sample, were used aliquots of $0.5 \mathrm{~g}$ in triplicate, which were mixed with $10 \mathrm{ml}$ methanol $95 \%$ containing $1 \% \mathrm{HCl}$ conc. and homogenized under sonication $15 \mathrm{~min}$. After 30 minutes, the extract was filtered by paper and Millipore PTFE membrane $(0.45 \mu \mathrm{m})$. The filtered sample was injected $(20 \mu \mathrm{l})$ in the HPLC column (Supelcosil LC 18, $250 \mathrm{~mm} \times 4.6 \mathrm{~mm} \times 5 \mu \mathrm{m})$ of an Agilent $1200 \mathrm{HPLC}$ device, with UV detection, applying an isocratic mobile phase consisting of acetonitrile: water, $9: 1$, flow $1 \mathrm{ml} / \mathrm{min}$. The run temperature at $25^{\circ} \mathrm{C}$ and the detection at $210 \mathrm{~nm}$ were set as optimum.

The concentrations of each component (BA and B) were calculated according to the calibration curve and expressed in mg per gram barks. The ratios of betulinic acid to betulin was calculated and expressed as percentage $(\mathrm{BA} / \mathrm{B} \times 100)$.

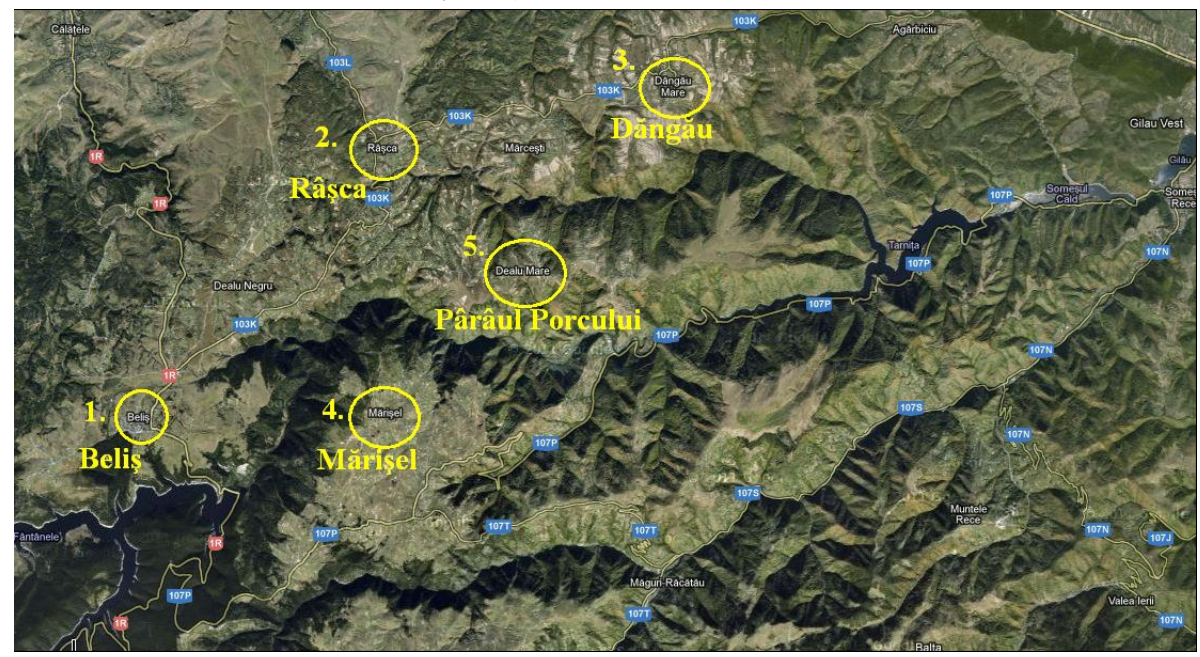

Fig. 2. Geographic position of the harvesting places (satellite picture) for samples 1-10

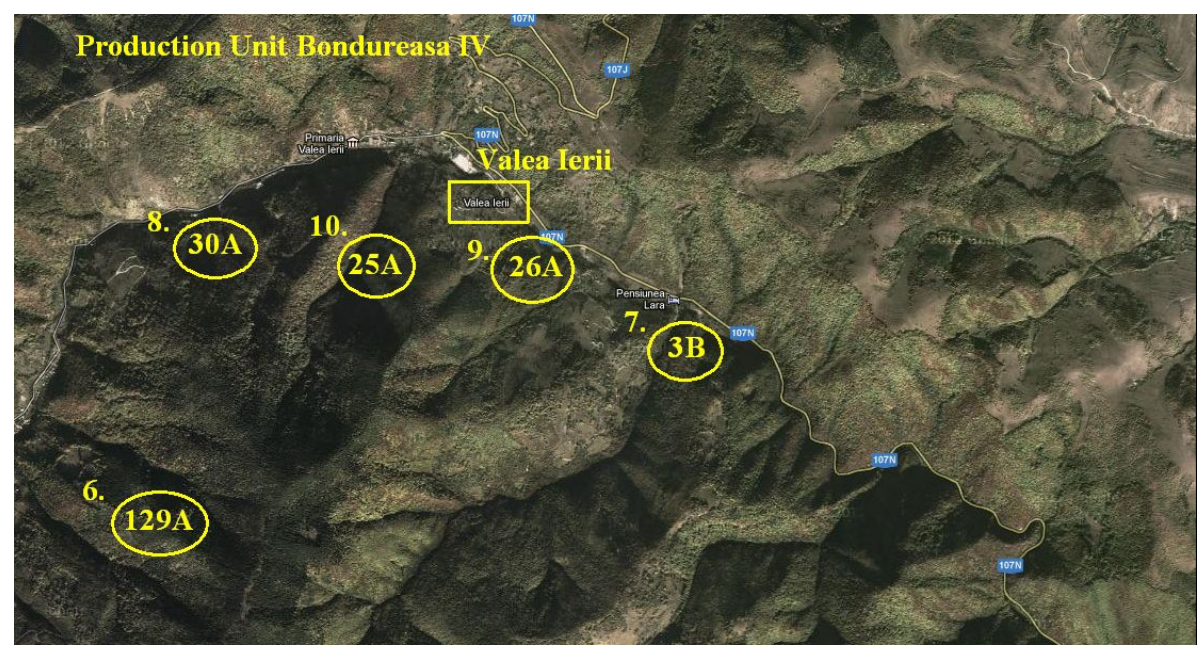

Fig. 3. Details about the surfaces with birches from where the samples 6-10 were harvested (Bondureasa region) 
102

Tab. 1. Samples of birch tree originating from Production Unit Bondureasa IV (samples 6 to 10)

\begin{tabular}{|c|c|}
\hline Nr. & Characterization of the specific areas from the Production Unit-region Bondureasa IV \\
\hline 1. & $\begin{array}{l}\text { Inferior versant, kneaded soil, South exhibition, altitude } 980 \mathrm{~m} \text { and slope angle } 38 \text { degree. Indicative flora: Asperula-Oxalis. Birch trees are } \\
\text { disseminated in the empty areas between forests of pine tree (P) and beech tree (B) (ratios of } 8 \mathrm{P}+2 \mathrm{~B} \text { ) with an average consistency of } 0.5 \text {. }\end{array}$ \\
\hline 2. & $\begin{array}{l}\text { Middle versant, kneaded soil, North exhibition, altitude } 1210 \mathrm{~m} \text { and slope angle } 40 \text { degree. Indicative flora: Vaccinium. } \\
\text { Birch trees }(\mathrm{Bi}) \text { are disseminated in forests of spruce fir }(\mathrm{S}) \text { (composition } 6 \mathrm{~S}+4 \mathrm{Bi} \text { ) with a consistency of } 0.3 \text {. }\end{array}$ \\
\hline 3. & $\begin{array}{l}\text { Inferior versant, waved soil, North-West exhibition, altitude } 920 \mathrm{~m} \text { and slope angle } 20 \text { degree. Indicative } \\
\text { flora: Asperula-Dentaria. Birch trees are disseminated in the empty areas between forests of pine } \\
\text { tree (P) and beech tree (B) (ratios of } 8 \mathrm{P}+2 \mathrm{~B}) \text { with an average consistency of } 0.6 \text {. }\end{array}$ \\
\hline 4. & $\begin{array}{l}\text { Middle versant, waved soil, West exhibition, altitude } 960 \mathrm{~m} \text { and slope ange } 25 \text { degree. Indicative flora: Asperula-Dentaria. } \\
\text { Birch trees }(\mathrm{Bi}) \text { are disseminated in pure forests of spruce fir }(\mathrm{S}) \text { (composition 10S) with an average consistency of } 0.7 \text {. }\end{array}$ \\
\hline 5. & $\begin{array}{l}\text { Inferior versant, kneaded soil, South exhibition, altitude } 980 \mathrm{~m} \text { and slope angle } 38 \text { degree. Indicative flora: Asperula-Oxalis. Birch trees are } \\
\text { disseminated in the empty areas between forests of pine tree (P) and beech tree (B) (ratios of 4P + 1B) with an average consistency of } 0.6 \text {. }\end{array}$ \\
\hline
\end{tabular}

\section{Results and discussion}

HPLC-UV analysis for the identification of betulin and betulinic acid

To identify accurately the betulin (B) and betulinic acid (BA), a mixture of pure standards was separated after a previous optimization of the separation protocol, established in the laboratory.

The standard curve for each compound was built in the concentration region of 0.01 to $0.1 \mathrm{mg} / \mathrm{ml}$ (data not shown) as well in a mixture ratio of 2:5, as shown in Fig. 4.

Betulinic acid (BA) and Betulin (B) concentrations in birch bark, depending on the region of harvest

The betulin peak was identified at $5.02 \mathrm{~min}$. for sample 4, from Marisel area (Fig. 5.). To identify correctly and accurately the peak position of betulinic acid (BA) $\left(t_{R}=4.45\right.$ $\mathrm{min}$ ), a minor component in this sample, it has been made a co-chromatography with pure BA. Actually the two close peaks in Fig. 5A correspond to 2 isomers of BA.
The mean values of the concentrations of betulinic acid (BA) and betulin (B) concentrations (expressed mg/g bark) determined in birch bark samples, originating from different regions and areas were presented in Tab. 2 .

The extraction solvent was chosen as $95 \%$ ethanol because betulin and betulinic acid could be extracted from white birch bark with a highest content. Results showed that all of the bioactive triterpenoid in white birch bark were strikingly dependent on the location (Tab. 2).

The results showed that content of the compounds were strongly dependent on the solvents with different polarities and similar studies (Zhao et al., 2007; Zhang et al., 2008). Ninety-five percent ethanol was a good extraction solvent that allowed extraction of triterpenoid with a highest content due to the co-solubility effect (Zhao et al., 2007).

In the first region (samples 1 to 5 ) it was found mean concentrations of $126.85 \pm 12.56 \mathrm{mg}$ betulin per $\mathrm{g}$ of bark, while acid betulinic had average values of $12.78 \pm 1.26$ $\mathrm{mg} / \mathrm{g}$ bark. In the second region (samples 6 to 10 ) it was found mean concentrations of $89.84 \pm 8.43 \mathrm{mg}$ betulin

Tab. 2. The mean values \pm SD of betulinic acid (BA) and betulin (B) concentrations (expressed mg/g bark) determined in triplicate from birch bark samples, originating from different regions and areas. The percentage of BA against $\mathrm{B}$ was calculated

\begin{tabular}{|c|c|c|c|c|}
\hline Nr. & Region of sample harvest & $\begin{array}{l}\text { Betulinic Acid (BA) } \\
(\mathrm{X} \pm \mathrm{SD})(\mathrm{mg} / \mathrm{g})\end{array}$ & $\begin{array}{c}\text { Betulin (B) }(X \pm S D) \\
(\mathrm{mg} / \mathrm{g})\end{array}$ & $\begin{array}{c}\text { Percentage }(\mathrm{BA} / \mathrm{B} \\
\times 100) \%\end{array}$ \\
\hline 1 & Belis & $11.64 \pm 1.23$ & $165.60 \pm 14.23$ & 7.00 \\
\hline 2 & Rasca & $14.68 \pm 1.50$ & $126.91 \pm 11.56$ & 11.56 \\
\hline 3 & Dangau & $12.31 \pm 1.07$ & $109.14 \pm 10.03$ & 11.27 \\
\hline 4 & Marisel & $11.15 \pm 1.11$ & $130.81 \pm 12.78$ & 8.52 \\
\hline 5 & Paraul Porcului & $14.15 \pm 1.39$ & $101.82 \pm 14.23$ & 13.89 \\
\hline \multicolumn{2}{|c|}{ Average values for regions 1-5 } & $12.78 \pm 1.26$ & $126.85 \pm 12.56$ & 10.44 \\
\hline 6 & $\mathrm{PU}^{*} \mathrm{IV}$ ua $129 \mathrm{~A}$ & $11.80 \pm 1.11$ & $81.99 \pm 7.83$ & 14.39 \\
\hline 7 & PU IV ua $3 \mathrm{~B}$ & $7.34 \pm 0.73$ & $57.44 \pm 5.02$ & 12.77 \\
\hline 8 & PU IV ua $30 \mathrm{~A}$ & $9.76 \pm 0.88$ & $86.17 \pm 8.62$ & 11.32 \\
\hline 9 & PU IV ua $26 \mathrm{~A}$ & $8.60 \pm 0.75$ & $77.98 \pm 7.83$ & 11.02 \\
\hline 10 & PU IV ua $25 \mathrm{~A}$ & $15.44 \pm 1.39$ & $145.63 \pm 12.86$ & 10.60 \\
\hline \multicolumn{2}{|c|}{ Average values for areas 6-10 (region 6) } & $10.60 \pm 0.97^{*}$ & $89.84 \pm 8.43^{* *}$ & 12.02 \\
\hline \multicolumn{2}{|c|}{ Average values for all samples } & $11.69 \pm 1.15$ & $108.34 \pm 10.49$ & 11.23 \\
\hline
\end{tabular}

${ }^{*} p<0.1 ;{ }^{* *} p<0.05$

${ }^{*} \mathrm{UP}$ - production unit 


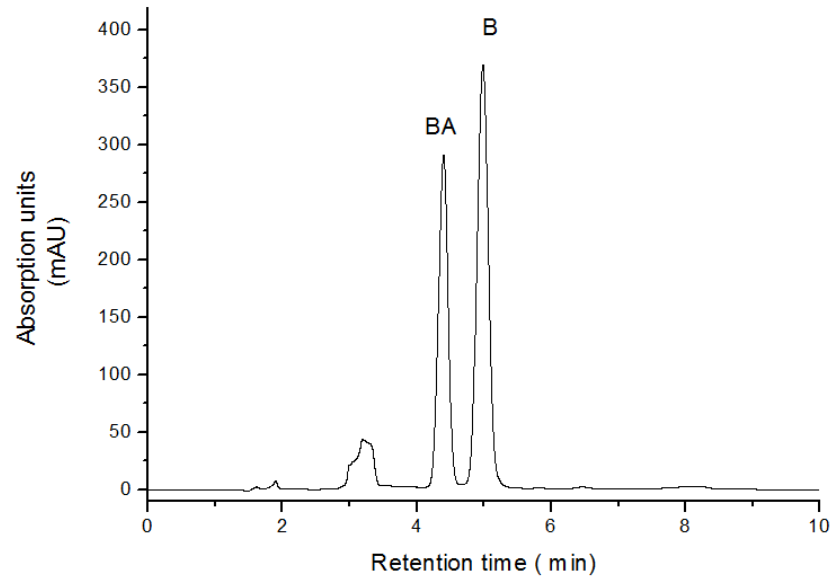

Fig. 4. The HPLC-UV chromatogram of a mixture of two pure standards of betulinic acid (BA) and betulin (B) at $0.02 \mathrm{mg} / \mathrm{ml}$ and $0.05 \mathrm{mg} / \mathrm{ml}$, respectively. Retention times: $\mathrm{t}_{\mathrm{R}}=4.45 \mathrm{~min}$ for $\mathrm{BA}$ and $\mathrm{t}_{\mathrm{R}}=5.02 \mathrm{~min}$ for $\mathrm{B}$. The detection was set at $210 \mathrm{~nm}$

per $g$ of bark, while acid betulinic had average values of $10.60 \pm 0.97 \mathrm{mg} / \mathrm{g}$ bark.

The content of betulin and betulinic acid varied significantly in the white birch bark in different locations. In the first region, Belis sample proved to be the richest in betulin concentrations of $165.60 \mathrm{mg} / \mathrm{g}$, and sample Rasca for betulinic acid with a concentration of $14.68 \mathrm{mg} / \mathrm{g}$. Sample PU IV 25A second region, recorded the highest concentration of betulin $(145.63 \mathrm{mg} / \mathrm{g})$ and betulinic acid $(15.44$ $\mathrm{mg} / \mathrm{g})$. Statistically, significant differences were noticed between the two regions of bark origin, the first region being richer in these molecules. The ratio of betulinic acid to betulin was calculated and expressed as percentage (BA/B $\times 100$ ). Generally, the percentage was around $11.23 \%$,

A.

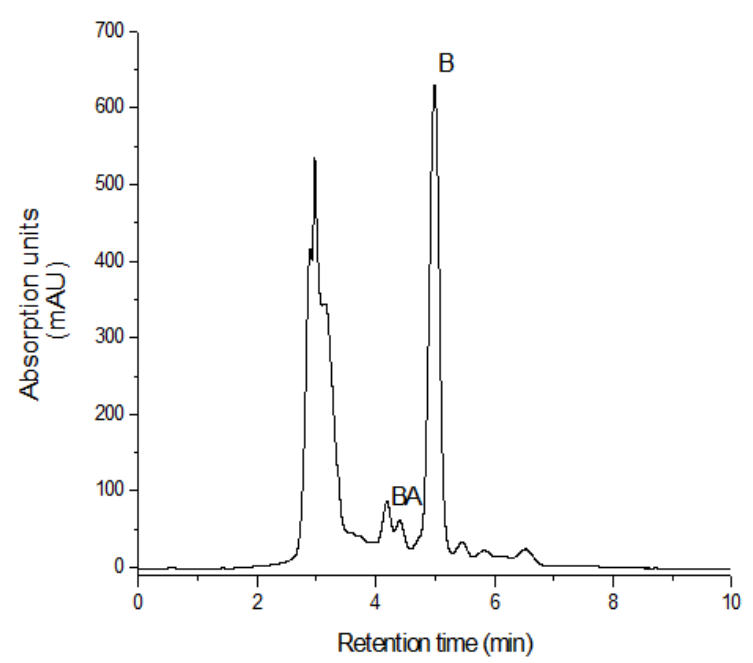

higher at the second region, even the absolute values were lower for the BA and B.

Betulin is a natural lupane-class triterpene derived from plants with a wide variety of biological activities. This compound group thus has wide medical potentials, and in fact has been shown to be active against intracellular pathogens (Salin et al., 2010).

Betulin can be used as extracted or, after chemical modification, as a starting compound for its acid, betulinic acid, with both substances possessing various pharmacological properties (Soica et al., 2012).

The data obtained are useful indicators of the potential offered by these birch bark sources found in Transylvania region (Romania), to obtain extracts enriched in betulin and betulinic acid. Further studies will focus on the bioconversion of betulin to betulinic acid using specific microorganisms and the study of the pharmacologic effects (as hepatoprotective and anticancer agents) of standardized.

\section{Conclusions}

The HPLC method mentioned here represented an excellent technique for simultaneous determination of betulin and betulinic acid in the extract of white birch bark, with good sensitivity, precision and reproducibility. The method gives a good resolution among betulin and betulinic acid with a short analysis. Significant variations in the content of betulin and betulinic acid in birch bark samples were recorded at Belis and Rasca in the first region and the sample PU IV 25 A second region. These data are useful indicators of the potential offered by birch bark sources found in Transylvania region, to obtain extracts enriched in betulin and betulinic acid.

B.

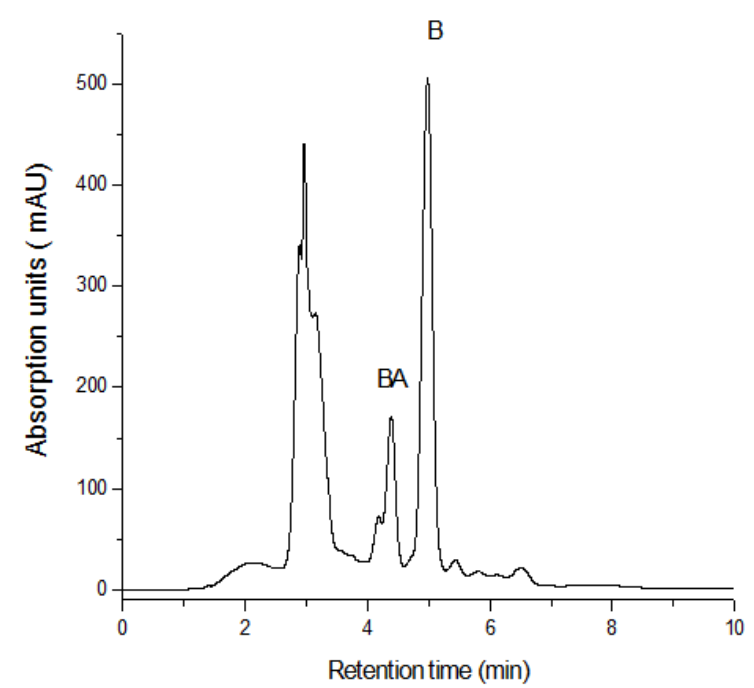

Fig. 5. A. HPLC-UV chromatogram of birch bark extract-sample 4 (from Marisel). B. Co-chromatogram of the sample 4 with pure standard of BA. Retention times: $t_{R}=4.45 \mathrm{~min}$ for BA and $t_{R}=5.02 \mathrm{~min}$ for $\mathrm{B}$. The detection was set at $210 \mathrm{~nm}$ 
104

\section{References}

Alakurtti S, Makela T, Koskimies S, Yli-Kauhaluoma J (2006). Pharmacological properties of the ubiquitous natural product betulin. Eur J Pharm Sci 29:1-13.

Cântă Pânzaru S, Leopold N, Kiefer W (2002). Vibrational spectroscopy of betulinic acid HIV inhibitor and of its birch bark natural source. Talanta 57:625-631.

Cichewicz RH, Kouzi SA (2004). Chemistry, biological activity, and chemotherapeutic potential of betulinic acid for the prevention and treatment of cancer and HIV infection. Med Res Rev 24:90-114.

Conway P (2002). Tree medicine: A comprehensive guide to the healing power of the 170 trees. London, Ed. Piatkus, 46 p.

Crevelin EJ, Turatti IC, Crotti AE, Veneziani RC, Lopes JL, Lopes NP, Cunha WR (2006). Identification of biologically active triterpenes and sterols present in hexane extracts from Miconia species using high-resolution gas chromatography. Biomed Chromatogr 20(8):827-830.

Dehelean CA, Cinta-Pinzaru S, Peev CI, Soica C, Antal DS (2007). Characterization of birch tree leaves, buds and bark dry extracts with antitumor activity. J Optoel Adv Mat 9:783-787.

Ekman R (1983). The suberin monomers and triterpenoids from the outer bark of betula verruosa ehrh. Holzforschung 37:205-211.

European Medicine Agency (EMA) (2007). Evaluation of Medicines for Human Use, Betula pendula, EMEA/ HMPC/207742/2007.

Falamas A, Cinta Pinzaru S, Dehelean CA (2011). Betulin and its natural resource as potential anticancer drug candidate seen by FT-Raman and FT-IR spectroscopy. J Raman Spectroscopy 42(1):97-107.

Fulda S (2008). Betulinic acid for cancer treatment and prevention. Int J Mol Sci 9:1096-1107.

Fulda S, Jeremias I, Steiner HH, Pietsch T, Debatin KM (1999). Betulinic acid: a new cytotoxic agent against malignant brain-tumor cells. Int J Cancer 82:435-441.

Gessner O (1974). Gift- und Azneipflanzen von Mitteleuropa. Betula pendula. 3. Auflage. Heidelberg, Carl Winter Verlag.

Hayek EWH, Moche W, Sauter F (1989). A bicentinial of betulin, Phytochemistry 28:2229-2242.

Haralamb A (1956). Culture woody forest species, Ed AgroSilvica, Bucureşti.

Hoppe HA (1975). Drogenkunde. Betula pendula pubescens. 8. Auflage. Berlin, Walter de Gruyter Verlag.

Kovac-Besovic E, Duric K, Kalodera Z, Sofić E (2009 a). Identification and isolation of pharmacologically active terpenes in Betulae cortex, Betula pendula Roth, Betulaceae. Bosnian J Basic Med 9(1):32-38.

Kovac-Besovic E, Duric K, Kalodera Z, Sofić E (2009 b). Identification and isolation of betulin, betulinic acid and lupeol from birch bark. Planta Medica 75(9):126-133.
Kvasnica M, Sarek J, Klinotova E, Dzubak P, Hajduch M (2005). Synthesis of phthalates of betulinic acid and betulin with cytotoxic activity. Bioorgan Med Chem 13:3447-3454.

Ladynina EA, Morozova RS (1987). Phythotherapy. Leningrad, Meditsina.

Lahtinen M, Lempa K, Salminen J-P, Pihlaja K (2006). HPLC analysis of leaf surface flavonoids for the preliminary classification of birch species. Phytochem Analysis 17(3):197-203.

Laszczyk M, Jäger S, Simon-Haarhaus B, Scheffler A, Schempp CM (2006). Physical, chemical and pharmacological characterization of a new oleogel-forming triterpene extract from the outer bark of birch (betulae cortex). Planta Med 72:1389-1395.

Lavrjonov VK, Lavrjonova GV (2003). 500 important herbs. Donetsk, Stalker.

Mihailov IV (2002). Handbook of homeopathy. Ed. Astrel, Moscow, $95 \mathrm{p}$.

Muravjova DA, Samlina IA, Yakovlev GP (2002). Pharmacognosy. Meditsina Ed., Moscow.

O’Connell M, Bently M, Campbell C, Cole B (1998). Betulin and lupeol in bark from four white-barked birches. Phytochemistry 27:2175-2176.

Oh SH, Choi JE, Lim SC (2006). Protection of betulin against cadmium-induced apoptosis in hepatoma cells. Toxicology 220:1-12.

Ossipov V, Nurmi K, Loponen J, Haukioja E, Pihlaja K (1996). High-performance liquid chromatographic separation and identification of phenolic compounds from leaves of Betula pubescens and Betula pendula. J Chromatogr A 721:59-68.

Pezzuto JM, Das Gupta TK, Schmidt ML, Kuzmanoff K, Ling-Indeck L, Kim D (1999). Method and composition for treating cancers. US Patent 5:962. USA: The Board of Trustees of the University of Illinois.

Rajendran P, Jaggi M, Singh MK, Mukherjee R, Burman AC (2008). Pharmacological evaluation of C-3 modified betulinic acid derivatives with potent anticancer activity. Invest New Drugs 26:25-34.

Sami A, Taru MK, Salme K, Jari YK (2006). Pharmacological properties of the ubiquitous natural product betulin. Eur J Pharm Sci 29:1-13.

Salin O, Alakurtti S, Pohjala L, Siiskonen A, Maass V, Maass M, Yli-Kauhaluoma J, Vuorela P (2010). Inhibitory effect of the natural product betulin and its derivatives against the intracellular bacterium Chlamydia pneumoniae. Biochemi Pharmacol 80:1141-1151.

Shikov Alexander N, Djachuk Georgy I, Sergeev Dmitry V, Pozharitskaya ON, Esaulenko EV, Kosman VM, Makarov VG (2011). Birch bark extract as therapy for chronic hepatitis C - A pilot study. Phytomedicine 18:807-810.

Soica CM, Dehelean CA, Peev C, Aluas M, Zupko I, Kasa P, Alexa E (2012). Physico-chemical comparison of betulinic acid, betulin and birch bark extract and in 
vitro investigation of their cytotoxic effects towards skin epidermoid carcinoma (A431), breast carcinoma (MCF7) and cervix adenocarcinoma (HeLa) cell lines. Nat Prod Res 26(10):968-974.

Stănescu V (1979). Dendrology. Ed. Didactic and Pedagogic Busuresti, $57 \mathrm{p}$.

Șofletea N, Curtu L (2000). Dendrology. $2^{\text {th }}$ Ed. For Life, 103 p.

Tamas M, Hodisan V, Grecu L, Fagarasan E, Baciu M, Muica I (1978). Research on indigenous herbal triterpenoid. Studii Cerc Biochim 21:89-94.

Turova AD (1974). Herbs in USSR and their use. Meditsina Ed., Moscow.

Vermeulen N (1999). Encyclopedia of herbs. Enkhuizen, Rebo Productions.

Wan Y, Wu1 YL, Lian LH, Xie WX, Li X, OuYang BQ, Bai T, Li Q, Yang N, Nan JX (2012). The anti-fibrotic effect of betulinic acid is mediated through the inhibition of NF-jB nuclear protein translocation. Chem-Biol Interact 195:215223.
Yin Y, Cui Y, Ding H (2008). Optimization of betulin extraction process from Inonotus Obliquus with pulsed electric fields. Innovative Food Science and Emerging Technologies 9:306310.

Zhao G, Yan W, Cao D (2007). Simultaneous determination of betulin and betulinic acid in white birch bark using RPHPLC. J Pharmaceut Biomed 43:959-962.

Zhang M, Zhang Y, Xie J (2008). Simultaneous determination of jujuboside A, B and betulinic acid in semen Ziziphi spinosae by high performance liquid chromatography-evaporative light scattering detection. J Pharmaceut Biomed 48:14671470.

Zuco V, Supino R, Righetti SC, Clerics K, Marchesi E, Gambacorti-Passerini C, Formelli F (2002). Selective cytotoxicity of betulinic acid on tumor cell lines but not normal cells. Cancer Lett 175:17-25. 